\title{
Types and Morphometric Study of Calcaneal Articular Facets on Human Tali of Thai Population
}

\author{
Tipos y Estudio Morfométrico de las Facetas Articulares Calcáneas \\ en Talus Humano de la Población Tailandesa
}

Nichapa Phunchago ${ }^{1}$; Nongnut Uabundit ${ }^{1}$; Kowit Chaisiwamongkol ${ }^{1}$; Amnart Chaichun ${ }^{1}$ \& Sitthichai Iamsaard ${ }^{1,2}$

PHUNCHAGO, N.; UABUNDIT, N.; CHAISIWAMONGKOL, K.; CHAICHUN, A. \& IAMSAARD, S. Types and morphometric study of calcaneal articular facets on human tali of Thai population. Int. J. Morphol, 36(3):975-978, 2018.

SUMMARY: Patterns and variant morphometries of calcaneal articular facets on talus are concerned before performing of joint ankle surgery, including used as a sex determination. Types of talar facets have been documented in many populations except in Thai race. Therefore, this study attempted to classify the types of talus facets and to measure the facet lengths on dried tali of Thais. The 372 dried tali (204 males, 168 females) from Khon Kaen University Bone Collection were observed for variant types and measured for their facet lengths. The facets were classified into 6 types: type I, tree facet are separated (1.88 \%); type II (A), the anterior and middle facets are partially connected with predominant ridge (34.68\%); type II (B), the anterior and middle facets are partially connected with slight ridge $(32.53 \%)$; type III, the anterior and middle facets are fully fused to form a single facet (2.96\%); type IV, the anterior and middle facets are partially separated by a ridge and partly by a groove $(27.42 \%)$; type V, all facets are continuous fused to form a single facet $(0.54 \%)$. In addition, the morphometric lengths of AP (anterior to posterior process) and ML1\&2 (medial to lateral process) in male are significantly greater than those of female. The AP, ML, and ML2 of male are 56.71 $\pm 0.16,41.63 \pm 0.18$, and $37.85 \pm 0.36 \mathrm{~mm}$, while of female are $51.21 \pm 0.12,37.74 \pm 0.16$, and $33.85 \pm 0.28 \mathrm{~mm}$, respectively. This incidence can be used as ankle surgery consideration and an anthropological marker for sex determination of unidentified talus.

KEY WORDS: Types; Morphometric study; Calcaneal articular facets; Thai talus.

\section{INTRODUCTION}

In general, the talocalcaneal joint, a major synovial subtalar joint, is functionally important for ankle movements such as in version and eversion of the foot. This joint id formed by articulating of superior facets of calcaneal bone to calcaneal articular facets of the talus. The incidence and variations of types of subtalar joint facets have been reported in many populations (Arora et al., 1979; Bilodi, 2006; Kaur et al., 2011; Garg et al., 2013; Jung et al., 2015). In addition, parts of the tarsal bones are also interested to be good candidate for sex and age determinations in the forensic research fields (Bidmos \& Asala, 2004; Tuller \& Duric, 2006; Harris \& Case, 2012; Mahakkanukrauh et al., 2014). In the literature reviews, the calcaneal articular facets have been classified into five to six subtypes (Arora et al.; Bilodi \& Agrawal, 2003; Bilodi; Kaur et al.; Jung et al.). It has been found that the types of subtalar joint facets are different in many races. In this issue, the morphological classification and morphometry of tali on the basis of calcaneal articular facets in Thais especially in Northeastern population have never been documented. Although we have previously reported the patterns of superior articulating facet of dried calcanei in our population already (Iamsaard et al., 2015), their facets on tali need to be further observed. Therefore, we attempted to investigate both types and possible lengths of individual facets on dried tali from our identified bone collection.

\section{MATERIAL AND METHOD}

The identified 372 dried tali (204 males, 168 females) from Khon Kaen University Bone Collection were observed for variant types and measured for their facet lengths. The age ranges of skeletal samples were approximately 20-80 year olds. The osteoporosis, osteophytes, or fractures of tali 
was excluded. The complete bone facets were recorded as classified for the types and incidence as shown in Figure 1.

The morphometric study: the digital caliper vernier gauge micrometer was used to measure the individual length of facets as followings (also shown in Fig. 1):

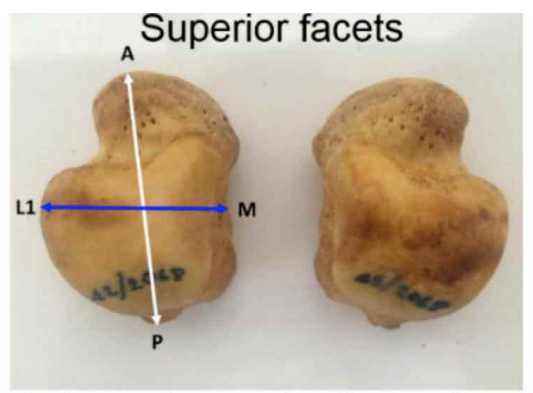

Inferior calcaneal articular facets

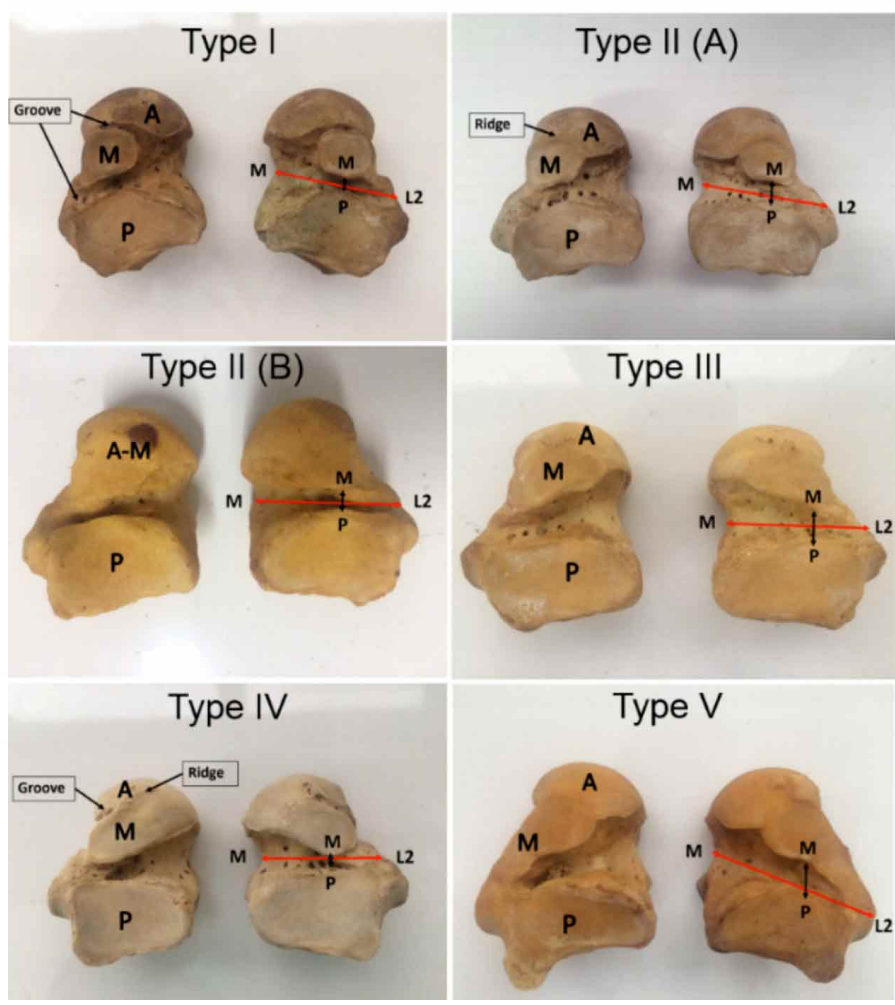

Fig 1. Showing types of calcaneal articular facets of talus and morphometric measurements on superior and inferior talar facets. Type I, tree facet are separated; Type II (A), the anterior and middle facets are partially connected with predominant ridge; Type II (B), the anterior and middle facets are partially connected with slight ridge; type III, the anterior and middle facets are fully fused to form a single facet; type IV, the anterior and middle facets are partially separated by a ridge and partly by a groove; type $\mathrm{V}$, all facets are continuous fused to form a single facet. A, M, and P; anterior, middle, and posterior facets, respectively. AP; maximal length from anterior to posterior talar process, ML1; length from medial to lateral talar process (superior facet view), ML2; length from medial to lateral talar process (inferior facet view), MP; length of groove between middle and posterior facets.
AP is the maximal length from anterior (A) to posterior talar process $(\mathrm{P})$

ML1 (superior facet aspect) is the length from medial (M) to lateral talar process (L1)

ML2 (inferior facet aspect) is the length from medial (M) to lateral talar process (L2) MP is the length of groove between middle $(\mathrm{M})$ and posterior facets $(\mathrm{P})$

The measurements were performed in triplicates by internal and external examiners. This study was approved for human ethic (no. HE591164) from the office of the Khon Kaen University ethics committee in human research.

\section{RESULTS}

The calcaneal articulating facets observed in Thai population were classified into 6 types as shown in Figure 1: Type I, tree facet are separated ; Type II (A), the anterior and middle facets are partially connected with predominant ridge; Type II (B), the anterior and middle facets are partially connected with slight ridge; Type III, the anterior and middle facets are fully fused to form a single facet; Type $\mathrm{IV}$, the anterior and middle facets are partially separated by a ridge and partly by a groove; Type V, all facets are continuous fused to form a single facet.

In Table I, the results showed that the incidence of type IIA was highest $(34.68 \%)$, followed by type II B (32.53\%), type IV $(27.42 \%)$, type III (2.96\%), type I (1.88 \%), and type V (0.54 $\%)$, respectively. However, it was found that highest incidence in male was type II (B), approximately $32.84 \%$ whereas in female was type II (B), approximately $42.89 \%$ (Table I).

In comparison, Table II showed significant average lengths of AP, ML1, and ML2 in male than that of female. The AP, ML, and ML2 of male are $56.71 \pm 0.16,41.63 \pm 0.18$, and $37.85 \pm 0.36 \mathrm{~mm}$, while of female are $51.21 \pm 0.12,37.74 \pm 0.16$, and $33.85 \pm 0.28 \mathrm{~mm}$, respectively. There is no statistical difference between left $\&$ right sides of individual parameter in both male and female (Table II). It was found that MP length of both sexes is not significantly different (of male, $5.44 \pm 0.17 \mathrm{~mm}$ and of female, $5.35 \pm 0.15 \mathrm{~mm}$ ) shown in Table II. 
Table I. Incidence of calcaneal articular facets on Thai- dried tali.

\begin{tabular}{cccccccc}
\hline Sex & Age & \multicolumn{6}{c}{ types of calcaneal articular facet on talus } \\
& & I & II (A) & II (B) & III & IV & V \\
\hline Male & & 6 & 57 & 67 & 8 & 66 & 0 \\
\hline$(\mathrm{n}=204$ tali) & $65.08 \pm 13.99$ & $(2.94 \%)$ & $(27.94 \%)$ & $(32.84 \%)$ & $(3.92 \%)$ & $(32.35 \%)$ & $(0 \%)$ \\
Female & & 1 & 72 & 55 & 3 & 36 & 2 \\
$(\mathrm{n}=168$ tali) & $60.03 \pm 14.77$ & $(0.6 \%)$ & $(42.86 \%)$ & $(32.14 \%)$ & $(1.79 \%)$ & $(21.43 \%)$ & $(1.19 \%)$ \\
Total & & 7 & 129 & 121 & 11 & 102 & 2 \\
$(\mathrm{n}=372$ tali) & $62.55 \pm 14.38$ & $(1.88 \%)$ & $(34.68 \%)$ & $(32.53 \%)$ & $(2.96 \%)$ & $(27.42 \%)$ & $(0.54 \%)$ \\
\hline
\end{tabular}

Age data are expressed as means \pm standard deviations.

Table II. Comparison of talar parameter lengths between left and right side of male and female Thai population.

\begin{tabular}{|c|c|c|c|c|c|c|}
\hline \multirow[t]{2}{*}{ Parameters $(\mathrm{mm})$} & \multicolumn{3}{|c|}{ Male $(\mathrm{n}=204$ tali) } & \multicolumn{3}{|c|}{ Female ( $\mathrm{n}=168$ tali) } \\
\hline & Left & Right & Average & Left & Right & Average \\
\hline AP & $56.77 \pm 0.15 \mathrm{a}$ & $56.64 \pm 0.16 b$ & $56.71 \pm 0.16 \mathrm{c}$ & $51.18 \pm 0.11$ & $51.24 \pm 0.13$ & $51.21 \pm 0.12$ \\
\hline ML1 & $41.61 \pm 0.19 \mathrm{a}$ & $41.64 \pm 0.16 \mathrm{~b}$ & $41.63 \pm 0.18 \mathrm{c}$ & $37.69 \pm 0.20$ & $37.78 \pm 0.12$ & $37.74 \pm 0.16$ \\
\hline ML2 & $37.61 \pm 0.36 \mathrm{a}$ & $38.08 \pm 0.35 \mathrm{~b}$ & $37.85 \pm 0.36 \mathrm{c}$ & $33.74 \pm 0.29$ & $33.96 \pm 0.26$ & $33.85 \pm 0.28$ \\
\hline MP & $5.65 \pm 0.13$ & $5.45 \pm 0.15$ & $5.55 \pm 0.14$ & $5.44 \pm 0.17$ & $5.26 \pm 0.13$ & $5.35 \pm 0.15$ \\
\hline
\end{tabular}

Data are expressed as means \pm standard deviations. a $\mathrm{p}<0.05$, compared between left tali of male and female; $\mathrm{b} p<0.05$, compared between right tali of male and female; $\mathrm{c} p<0.05$, compared between left \& right-averaged lengths of male and female. AP; maximal length from anterior to posterior talar process, ML1; length from medial to lateral talar process (superior facet view), ML2; length from medial to lateral talar process (inferior facet view), MP; length of groove between middle and posterior facets.

\section{DISCUSSION}

It is known that the subtalar region of different population is a common site of anatomical variation because of individual ligamentous structures, lesser extent, and osseous morphology. The variations of subtalar joints are clinically concerned in ankle surgeries including talo-calcaneal coalition. Previously, the types and incidence of superior articular facets of Isan-Thai dried calcanei has been documented for the first time (Iamsaard et al.). Present study has also demonstrated that the calcaneal articulating facets of dried tali observed in our population could be classified into 6 types (I, II [A], II [B], III, IV, and V, respectively) with morphometry of their facets as also shown in Figure 1. This finding is similar to that of previous investigations (Arora et al.; Bilodi \& Agrawal; Bilodi; Kaur et al.; Garg et al.; Jung et al.). However, the types of single calcaneal facet (continuous with posterior calcaneal facet; $15 \%$ in India) and two calcaneal facets (continuous between middle and posterior calcaneal facets; 3 $\%$ in India), observed by Garg et al., were not found in resent study. Compared to Indian populations, it was found that type II (A) in our classification has highest incidence (34.68 \%), similar to previous studies that this types of faces were predominantly observed approximately $43-78 \%$ (Kaur et al.; Garg et al.; Rehman, 2014). Moreover, this study attempted to perform the morphometric measurements on superior and inferior talar facets (Fig. 1 and Table II). Interestingly, it was found that the average lengths of AP, ML1, and ML2, but not
MP in male were significantly longer than that of female. We assumed that males might bear the skeletal weights more than female resulting in subtalar bones including morphometric tali expanded in males. In conclusion, the incidence of articular surface of the talus and significant morphometric data can be used as basic information for ankle surgery consideration and an anthropological marker for sex dimorphism of unknown tali.

\section{ACKNOWLEDGMENTS}

We would like to express our gratefully thank the invitation research grants from Faculty of Medicine, Khon Kaen University for financial support of this project (no. IN59223) to Dr. Nichapa Phunchago and Dr. Sitthichai Iamsaard.

PHUNCHAGO, N.; UABUNDIT, N.; CHAISIWAMONGKOL, K.; CHAICHUN, A. \& IAMSAARD, S. Estudio morfométrico y tipos de facetas articulares calcáneas en el talus humano en una población tailandesa. Int. J. Morphol., 36(3):975-978, 2018.

RESUMEN: Los patrones y las variantes morfométricas de las facetas articulares calcáneas en el talus deben considerarse 
antes de la realización de la cirugía del tobillo a nivel articular, incluido su uso para la determinación del sexo. Se han documentado los tipos de facetas en el talus en muchas poblaciones, excepto en la raza tailandesa. Por lo tanto, este estudio clasificó los tipos de facetas del talus y se midieron las longitudes de las facetas del talus, en muestras secas de indiviuos tailandeses. Se analizaron 372 talus secos (204 de hombres, 168 de mujeres) de la colección de huesos de la Universidad Khon Kaen, se observaron distintos tipos de variantes y se midieron las longitudes de las facetas. Las facetas se clasificaron en 6 tipos: tipo I, faceta de árbol separadas $(1,88 \%)$; tipo II (A), facetas anterior y media parcialmente conectadas con la cresta predominante $(34,68 \%)$; tipo II (B), facetas anterior y media están parcialmente conectadas con una ligera cresta $(32,53 \%)$; tipo III, facetas anterior y media están completamente fusionadas para formar una sola faceta $(2,96 \%)$; tipo IV, facetas anterior y media están parcialmente separadas por una cresta y en parte por una ranura $(27,42 \%)$; tipo $\mathrm{V}$, todas las facetas se fusionan continuamente para formar una sola faceta $(0,54 \%)$. Además, las longitudes morfométricas del proceso anterior o posterior (AP) y del proceso medial a lateral (ML1 y ML2) en el varón son significativamente mayores que las de la mujer. El AP, ML1 y ML2 de los hombres son $56,71 \pm 0,16,41,63 \pm 0,18$ y $37,85 \pm 0,36 \mathrm{~mm}$, mientras que las mujeres son $51,21 \pm 0,12,37,74 \pm 0,16$ y $33,85 \pm$ $0,28 \mathrm{~mm}$, respectivamente. Esta incidencia se puede utilizar como una consideración en la cirugía de tobillo y un marcador antropológico para determinar el sexo del talus no identificado.

PALABRAS CLAVE: Tipos; Estudio morfométrico; Facetas articulares del calcáneo; Talus; Tailandia.

\section{REFERENCES}

Arora, A. K.; Gupta, S. C.; Gupta, C. D. \& Jeyasingh, P. Variations in calcanean facets in Indian Tali. Anat. Anz., 146(4):377-80, 1979.

Bidmos, M. A. \& Asala, S. A. Sexual dimorphism of the calcaneus of South African blacks. J. Forensic Sci., 49(3):446-50, 2004.

Bilodi, A. K. \& Agrawal, B. K. Study of fifty human tali for calcaneal articular facets. Kathmandu Univ. Med. J., 2(3):213-5, 2003.

Bilodi, A. K. Study of calcaneal articular facets in human tali. Kathmandu Univ. Med. J. (KUMJ), 4(1):75-7, 2006.

Garg, R.; Babuta, S.; Mogra, K.; Parashar, R, \& Shekhawat, S. Study of Variations in Pattern of Calcaneal Articular Facets in Human Tali in the Population of Rajasthan (India). People's J. Sci. Res., 6(2):1923, 2013.

Harris, S. M. \& Case, D. T. Sexual dimorphism in the tarsal bones: implications for sex determination. J. Forensic Sci., 57(2):295-305, 2012.

Iamsaard, S.; Uabundit, N.; Boonruangsri, P.; Sawatpanich, T. \& Hipkaeo, W. Types of facets on the superior articular surface of Isan-Thai dried calcanei. Int. J. Morphol., 33(4):1549-52, 2015.

Jung, M. H.; Choi, B. Y.; Lee, J. Y.; Han, C. S.; Lee, J. S.; Yang, C. Y. \& Cho, B. P. Types of subtalar joint facets. Surg. Radiol. Anat., 37(6):629-38, 2015.

Kaur, M.; Kalsey, G. \& Laxmi, V. Morphological classification of tali on the basis of calcanean articular facets. Pb J. Orthop., 12(1):57-60, 2011.

Mahakkanukrauh, P.; Praneatpolgrang, S.; Ruengdit, S.; Singsuwan, P.; Duangto, P. \& Case, D. T. Sex estimation from the talus in a Thai population. Forensic Sci. Int., 240:152.e1-8, 2014.
Rehman, F. U. Study of human fetal tali calcaneal articular facets. Int. J. Dev. Res., 4(7):1362-5, 2014.

Tuller, H. \& Duric, M. Keeping the pieces together: comparison of mass grave excavation methodology. Forensic Sci. Int., 156(2-3):192-200, 2006.

Corresponding author:

Dr. Sitthichai lamsaard

Department of Anatomy

Faculty of Medicine

Khon Kaen University

123 Mitrapap Road

Amphoe Muang

Khon Kaen 40002

THAILAND

E-mail: sittia@kku.ac.th

Received: 24-01-2018

Accepted: 30-03-2018 